\title{
Pengembangan Bahan Ajar Berbasis Situs Astana Gede Kawali Untuk Meningkatkan Ketahanan Budaya Lokal Siswa
}

\author{
Aan Suryana*, Dewi Ratih \\ Universitas Galuh Ciamis \\ ${ }^{*}$ Corresponding author`s e-mail: aansuryana64@gmail.com
}

\begin{abstract}
This study aims to develop teaching material based on local history displaying the existence of the site of Kawali's Astana Gede to improve the preservation of students' culture and analyze the product effectiveness of teaching material applied in History learning. This study was conducted in SMA Plus Informatika Ciamis using Reseach \& Development (R\&D) by Borg \& Gall. The result of the study showed that; 1) model, method, and teaching material applied by most of History teachers in SMA Plus Informatika Ciamis still use teaching model or method dominated by the teacher and the history teacher still applies available teaching material at school; 2) The use local history site as the teaching material hasn't been implemented optimally in learning process; 3) The development of teaching material based on local history of Kawali's Astana Gede is conducted by developing available teaching material and designing the innovation in accordance with Competence Standard, Basic Competence and main learning material. The application of the teaching material based on the local material of the site of Kawali's Astana Gede is effective to improve the preservation of students' local culture and the good History learning outcome. This is indicated from the result of high learning evaluation and good learning activity.
\end{abstract}

Keywords: Astana Gede, The Preservation of Culture, History

Abstrak: Penelitian ini bertujuan untuk mengembangkan bahan ajar berbasis sejarah lokal dengan menampilkan eksistensi Situs Astana Gede Kawali untuk meningkatkan ketahanan budaya siswa, serta menganalisis keefektifan produk bahan ajar yang digunakan dalam pembelajaran sejarah. Penelitian ini dilaksanakan di SMA Plus Informatika Ciamis dengan menggunakan metode penelitian Reseach \& Development (R\&D) dari Borg \& Gall. Hasil penelitian menunjukan: 1) model dan metode pembelajaran yang diterapkan masih didominasi oleh guru dan masih menggunakan bahan ajar yang sudah disediakan di sekolah; 2) Penggunaan situs sejarah lokal sebagai bahan ajar dalam proses pembelajaran belum dilakukan secara optimal; 3) Pengembangan bahan ajar berbasis sejarah lokal Situs Astana Gede Kawali dilakukan dengan mengembangkan bahan ajar yang sudah ada dan dilakukan pembaharuan serta disesuaikan dengan Standar Kompetensi, Kompetensi Dasar dan Materi Pokok pembelajaran. Penerapan bahan ajar berbasis sejarah lokal Situs Astana Gede Kawali efektif meningkatkan ketahanan budaya dan hasil belajar siswa. Hal ini ditunjukkan dari hasil evaluasi belajar yang sangat tinggi dan aktivitas pembelajaran yang sangat baik.

Kata kunci: Astana Gede, Ketahanan Budaya, Sejarah

\section{Pendahuluan}

Sejarah lokal dapat didefenisikan sebagai sejarah dari suatu "tempat", suatu "locality", yang batasannya ditentukan oleh perjanjian yang diajukan penulis sejarah (Hardiana, 2017). Selanjutnya, sejarah lokal sangat penting bagi kehidupan masyarakat terutama masyarakat modern. Pada dasarnya mempelajari sejarah lokal sangat bermanfaat yakni sebagai sumber kreativitas dan pandangan optimis masyarakat lokal (Kusnoto \& Minandar, 2017). Dalam negara kesatuan seperti Indonesia ini membicarakan sejarah lokal 
bukan berarti berfikiran mundur, karena banyak peristiwa historis di tingkat lokal merupakan dimensi dari sejarah nasional. Penelitian tentang sejarah lokal akan memperdalam pengetahuan tentang dinamika sisiokultural dari bangsa Indonesia yang majemuk secara lebih dekat. Sering kali hal-hal yang ada di tingkat nasional baru dapat dimengerti dengan baik apabila kita mengerti dengan baik pula perkembangan yang ada pada tingkat yang lebih kecil. Ada beberapa hal pentingnya mempelajari sejarah lokal:

1. Untuk menilai kembali generalisasi-generalisasi yang sering terdapat dalam sejarah nasional (periodisasi, dualisme ekonomi, dll).

2. Meningkatkan wawasan/ pengetahuan kesejahteraan dari masing-masing kelompok yang akhirnya akan memperluas pandangan tentang dunia Indonesia.

3. Membantu sejarawan profesional membuat analisis-analisis kritis.

4. Menjadi sumber/ bahan/ data sejarah untuk kepentingan nomor satu dan para peneliti lainnya (Darmawan, n.d.).

Dalam kegiatan pembelajaran sejarah di sekolah, mempelajari sejarah lokal sangatlah penting untuk dapat menumbuhkan ketahanan budaya siswa, karena ketika ketahanan budaya siswa tinggi, maka mereka akan mampu menerima segala perbedaan yang ada. Salah satu cara supaya sejarah lokal dipelajari siswa di sekolah adalah dengan dibuatnya bahan ajar yang khusus menceritakan tentang sejarah yang dekat dengan lingkungan mereka. Namun realitasnya, bahan ajar dalam pembelajaran sejarah selama ini masih terpaku pada bahan ajar sejarah nasional. Sementara untuk bahan ajar sejarah lokal hampir disetiap sekolah yang ada di kabupaten Ciamis belum diaplikasikan, sehingga banyak diantara siswa khususnya tingkat SMA tidak mengetahui sejarah daerahnya sendiri. Hal ini yang menarik perhatian peneliti untuk melaksanakan penelitian dengan mengembangkan bahan ajar yang berbasis sejarah lokal berupa modul pada mata pelajaran sejarah.

Hal ini sesuai hasil penelitian yang dilakaukan oleh Wijayanti dan Pajriah (2016), dengan judul "Media Pembelajaran Berbasis Audio Visual Situs Kerajaan Galuh di Ciamis Untuk Meningkatkan Kesadaran Siswa di SMA N 1 Ciamis" yang menunjukan bahwa adanya pengembangan video/audio visual situs sejarah kerajaan Galuh efektif meningkatkan kesadaran sejarah siswa. Selain itu, hasil penelitian Anggoro, dkk (2020) menunjukan adanya perbedaan efek penggunaan bahan ajar terhadap peningkatan nasionalisme siswa mencapai $25,17 \%$ dengan nilai probabilitas $=0,00$ lebih kecil daripada alpha $=0,05$. Modul terbukti memberi pengaruh lebih besar terhadap peningkatan nasionalisme siswa dibanding bahan ajar konvensional (handout) dengan skor rerata posttest nasionalisme kelas eksperimen sebesar 85,53 (sangat baik) sedangkan kelas kontrol 77,00 (baik). Merujuk penjelasan tersebut, diperlukan sebuah inovasi pengembangan bahan ajar berbasis sejarah lokal dalam 
kegiatan pembelajaran sejarah. Pentingnya inovasi bahan ajar sejarah lokal adalah akan mempermudah mengenalkan sejarah yang ada di lingkungan sekitar siswa kepada mereka. Pembelajaran yang telah disusun berdasarkan kurikulum yang ada di sekolah. Salah satu bahan ajar berbasis sejarah lokal yang akan digunakan peneliti adalah dengan menampilkan Situs Astana Gede Kawali yang ada di kabupaten Ciamis. Adapun pertimbangan peneliti mengambil Situs Astana Gede Kawali sebagai bahan ajar karena, dalam situs ini terdapat hubungan yang sangat erat dengan sejarah perkembangan kabupaten Ciamis. Penggunaan bahan ajar berbasis sejarah lokal pun merupakan salah satu usaha untuk memudahkan guru dalam menyampaikan informasi tentang sejarah lokal yang ada di kabupaten Ciamis. Salah satunya, di sekolah SMA Informatika Ciamis. Salah satu alasan SMA Informatika Ciamis dijadikan objek penelitian adalah, karena di sekolah ini sudah mulai diterapkan pembelajaran sejarah dengan mengaitkan peristiwa-peristiwa lokal ke dalam pembelajaran. Dalam hal ini akan diintegrasikan peristiwa sejarah yang dekat dengan lingkungan siswa ke dalam kegiatan pembelajaran yang disesuaikan dengan kurikulum di sekolah bersangkutan.

\section{Metode}

Metode Kegiatan penelitian ini menggunakan metode Reseach and Development. Karena dengan metode ini akan mengembangkan bahan ajar berbasis sejarah lokal yang nantinya menghasilkan produk bahan ajar berupa modul pembelajaran berbasis sejarah lokal dengan menampilkan Situs Astana Gede Kawali. Ada 10 tahapan dalam mengembangkan model, yaitu:

1. Research and information collecting, termasuk dalam langkah ini antara lain studi literatur yang berkaitan dengan permasalahan yang dikaji, pengukuran kebutuhan, penelitian dalam skala kecil, dan persiapan untuk merumuskan kerangka kerja penelitian;

2. Planning, termasuk dalam langkah ini menyusun rencana penelitian yang meliputi merumuskan kecakapan dan keahlian yang berkaitan dengan permasalahan, menentukan tujuan yang akan dicapai pada setiap tahapan, desain atau langkah-langkah penelitian dan jika mungkin/diperlukan melaksanakan studi kelayakan secara terbatas;

3. Develop preliminary form of product, yaitu mengembangkan bentuk permulaan dari produk yang akan dihasilkan. Termasuk dalam langkah ini adalah persiapan komponen pendukung, menyiapkan pedoman dan buku petunjuk, dan melakukan evaluasi terhadap kelayakan alat-alat pendukung;

4. Preliminary field testing, yaitu melakukan ujicoba lapangan awal dalam skala terbatas, dengan melibatkan 1 sampai dengan 3 sekolah, dengan jumlah 6-12 subyek; 
5. Operational product revision, yaitu melakukan perbaikan/penyempurnaan terhadap hasil ujicoba lebih luas, sehingga produk yang dikembangkan sudah merupakan desain model operasional yang siap divalidasi;

6. Operational field testing, yaitu langkah uji validasi terhadap model operasional yang telah dihasilkan. Pengujian dilakukan melalui angket, wawancara, dan observasi dan analisis hasilnya;

7. Final product revision, yaitu melakukan perbaikan akhir terhadap model yang dikembangkan guna menghasilkan produk akhir (final);

8. Dissemination and implementation, yaitu langkah menyebarluaskan produk/model yang dikembangkan kepada khalayak/masyarakat luas, terutama dalam kancah pendidikan. Langkah pokok dalam fase ini adalah mengkomunikasikan dan mensosialisasikan temuan/model, baik dalam bentuk seminar hasil penelitian, publikasi pada jurnal, maupun pemaparan kepada stakeholders yang terkait dengan temuan penelitian (Haryati, 2012).

Tujuan dari metode Reseach and Development adalah menjembatani kesenjangan antara sesuatu yang terjadi dalam penelitian pendidikan dengan praktik pendidikan, menghasilkan produk penelitian yang dapat digunakan untuk mengembangkan mutu pendidikan dan pembelajaran secara efektif (Anik, 2011). Populasi dalam penelitian ini adalah siswa kelas X SMA Plus Informatika Ciamis, yaitu kelas X IPA 2 dan IPA 1. Kelas eksperimen diberi pembelajaran dengan menggunakan modul hasil pengembangan dan kelas kontrol diberi pembelajaran dengan menggunakan buku paket.

\section{Hasil Dan Pembahasan}

\section{A. Proses Pembelajaran Sejarah Yang Berlangsung Di SMA Plus Informatika Ciamis}

Pembelajaran merupakan suatu usaha yang dilakukan oleh seseorang untuk mendapatkan perubahan, terutama yang berkaitan dengan prilaku. Salah satu kegiatan pembelajaran yang penting dilakukan adalah pembelajaran sejarah. Pembelajaran sejarah memiliki arti yang sangat penting bagi perkembangan generasi penerus bangsa. Hal ini dikarenakan, melalui pembelajaran sejarah siswa akan mengenal tentang sejarah bangsanya. Selain itu, melalui pendidikan sejarah peserta didik diajak menelaah keterkaitan kehidupan yang di alami diri, masyarakat dan bangsanya, sehingga mereka tumbuh menjadi generasi muda yang memiliki kesadaran sejarah, mendapatkan inspirasi atau pun hikmah dari kisahkisah pahlawan, maupun tragedi nasional, yang pada akhirnya mendorong terbentuknya pola berfikir ke arah berfikir secara rasional-kritis-empiris, dan yang tidak kalah pentingnya ialah pembelajaran sejarah yang mengembangkan sikap mau menghargai nilai-nilai kemanusiaan 
(Wiyanarti, 2017). Kegiatan penelitian ini dilakukan di SMA Plus Informatika Ciamis kelas X IPA 1 dan 2. Berdasarkan hasil penelitian pendahuluan, bersama guru sejarah dan siswa kegiatan pembelajaran yang berlangsung di kelas X IPA SMA Plus Informatika Ciamis pada umumnya masih menggunakan metode ceramah, diskusi, dan penugasan, baik secara individu atau kelompok. Selain itu, kegiatan pembelajaran sejarah pun dilakukan dengan menerapkan model pembelajaran kooperatif seperti model pembelajaran kooperatif Jigsaw. Untuk bahan ajar, guru biasanya menggunakan bahan ajar dari buku teks yang sudah disediakan di sekolah. Sedangkan, untuk penggunaan bahan ajar yang berbasis sejarah lokal belum pernah digunakan. Hasil observasi awal menunjukan bahwa guru memiliki motivasi yang besar untuk menggunakan bahan ajar berbasis sejarah lokal yang dikolaborasikan dengan materi yang ada di sekolah, dengan tujuan untuk menanamkan dan mengenalkan siswa pada sejarah yang ada di daerahnya, sehingga diharapkan mampu meningkatkan ketahanan budaya mereka.

Hal ini berdasarkan pengalaman guru sejarah sendiri yang sudah memahami tentang pentingnya pembelajaran sejarah lokal bagi siswa. Namun, dibalik pentingya pembelajaran sejarah lokal bagi siswa di sekolah masih banyak kendala-kendala yang harus dihadapi oleh guru terutama yang berkaitan dengan sumber ataupun penggunaan waktu yang masih kurang efektif, karena harus menyesuaikan dengan materi yang ada di dalam silabus. Hal ini memerlukan kedisiplinan yang luar biasa baik dari guru atau siswa. Selain itu, berdasarkan hasil penelitian di lapangan siswa pun menunjukan rasa antusias yang tinggi untuk mempelajari sejarah lokal yang ada di kabupaten Ciamis, seperti Situs Astana Gede Kawali, karena proses pembelajaran sejarah yang berlangsung selama ini hanya menggunakan buku teks yang ada di sekolah.

Selanjutnya, siswa pun mengakui bahawa mereka belum mengetahui dan memahami secara jelas tentang sejarah Situs Astana Gede Kawali. Dengan adanya bahan ajar berbasis sejarah lokal Situs Astana Gede Kawali sebagai situs peninggalan kerajaan Galuh, selain mengenalkan dan meningkatkan pemahaman siswa tentang sejarah lokal yang ada di kabupaten Ciamis, juga diharapkan mampu meningkatkan ketahan budaya mereka. Penggunaan bahan ajar berbasis sejarah lokal sangatlah penting untuk diaplikasikan di sekolah-sekolah.. Melalui pengajaran sejarah lokal siswa diajak mendekatkan diri pada situasi riil dari lingkungan terdekatnya. Berikutnya membawa siswa secara langsung mengenal serta menghayati lingkungan masyarakat, di mana mereka adalah merupakan bagian dari padanya. Tidak salah bila dikatakan bahwa pengajaran sejarah lokal mampu menerobos batas antara "dunia sekolah" dengan "dunia nyata" di luar sekolah. Dari 
pengajaran sejarah lokal siswa akan mendapatkan banyak contoh-contoh dan pengalamanpengalaman dari berbagai tingkat perkembangan lingkungan masyarakatnya, termasuk situasi masa kininya. Mereka juga akan lebih terdorong mengembangkan keterampilanketerampilan khusus seperti perihal observasi, teknik bertanya atau melakukan wawancara, menyeleksi sumber, mencari fakta, dan lain-lain (Darmawan, n.d.). Selain itu, pengajaran sejarah lokal di sekolah, diharapkan mampu mengembangkan kompetensi siswa untuk berfikir secara kronologis dan siswa memiliki pengetahuan tentang masa lampau yang dapat digunakan untuk memahami dan menjelaskan proses perkembangan dan perubahan masyarakat serta keragaman sosial budaya, sehingga dengan memahami sejarah lokal, siswa dapat menemukan dan menumbuhkan jati diri bangsa di tengah-tengah kehidupan masyarakat dunia. Pembelajaran sejarah lokal juga membuka peluang lebih besar untuk terjadinya proses transmisi nilai kearifan lokal yang terkandung dalam budaya lokalitas setempat (Romadi \& Kurniawan, 2017).

\section{B. Pengembangan Bahan Ajar Berbasis Sejarah Lokal Situs Astana Gede Kawali dalam Pembelajaran Sejarah di SMA Plus Informatika Ciamis}

Situs Astana Gede Kawali merupakan situs peninggalan kerajaan Galuh yang merupakan cikal bakal kabupaten Ciamis saat ini. Pada situs ini terdapat banyak peninggalan bersejarah yang bercorak Hindu maupun Islam. Hal ini sangat penting diketahui oleh siswa supaya pemahaman mereka terhadap sejarah lokal yang ada di kabupaten Ciamis lebih luas dan diharapkan akan mampu meningkatkan ketahanan budaya siswa. Namun, untuk mengunjungi langsung situs bersejarah ini banyak sekali kendala yang harus dihadapi, terutama yang berkaitan dengan masalah waktu dan biaya. Maka berdasarkan hal tersebut dibuatlah bahan ajar sejarah lokal Situs Astana Gede Kawali berupa modul mata pelajaran sejarah untuk memudahkan siswa memahami tentang sejarah dan benda-benda peninggalan yang ada di dalamnya. Dalam proses pengembangan bahan ajar ini yang dihasilkan berupa modul mata pelajaran sejarah Situs Astana Gede Kawali.

Hal ini berdasarkan hasil temuan penelitian yang menunjukan selama ini proses pembelajaran sejarah hanya menggunakan bahan ajar berupa buku teks yang sudah disediakan di sekolah. Selain itu, kegiatan pembelajaran pun masih didominasi oleh kegiatan ceramah dan diskusi kelompok. Bahan ajar yang dikembangkan dalam kegiatan penelitian ini adalah bahan ajar berupa modul mata pelajaran sejarah yang di dalamnya menjelaskan tentang sejarah dan benda-benda peninggalan di Situs Astana Gede Kawali yang merupakan situs peninggalan kerajaan Galuh yang bercorak Hindu. Adapun materi Situs Astana Gede Kawali disampaikan kepada siswa berdasarkan silabus dan RPP yang ada di sekolah, yaitu pada Kompetensi Dasar (KD) “Kerajaan-Kerajaan yang Bercorak Hindu-Budha di Indonesia”. 
Bahan ajar berupa modul mata pelajaran sejarah dikembangkan melalui sembilan langkah (Novianti, 2015).

\section{Mengidentifikasikan tujuan pembelajaran}

Pembelajaran sejarah bertujuan untuk menjadikan manusia yang memiliki rasa nasionalisme dan patriotisme. Kompetensi dasar: memahami kerajaan-kerajaan yang bercorak Hindu-Budha di Indonesia. Sedangkan materi yang akan dikembangkan adalah kerajaan yang bercorak Hindu di Indonesia, yaitu kerajaan Galuh yang ada di Kabupaten Ciamis dengan peninggalannya berupa Situs Astana Gede Kawali.

\section{Melakukan analisis pembelajaran}

Pada kegiatan dilakukan penyusunan Rencana Pelaksanaan Pembelajaran pada pembelajaran sejarah Indonesia kelas X berdasarkan kurikulum 2013, terdiri dari KI (Kompetensi Inti), KD (kompetensi Dasar), indikator, tujuan pembelajaran, materi, langkahlangkah pemelajaran dan pendekatan pembelajaran, proses pembelajaran dan pembagian waktu, alat/media dan sumber belajar, serta evaluasi.

\section{Mengidentifikasi karakteristik siswa}

Karakteristik siswa kelas X SMA Plus Informatika Ciamis, yaitu bahwa pada awal pertemuan siswa memiliki kemampuan sedang dengan gaya belajar mandiri dan kelompok secara terbimbing dan pada umumnya siswa menyukai pelajaran sejarah, apalagi dikaitkan dengan sejarah yang dekat dengan lingkungan mereka. Namun, dalam hal ini masih banyak siswa yang belum mengetahui dan memahami tentang sejarah Situs Astana Gede Kawali.

\section{Membuat tujuan khusus pembelajaran}

Pada langkah ini dirumuskan tujuan khusus pembelajaran sejarah terutama yang berkaitan dengan mengaitkan materi sejarah lokal ke dalam materi sejarah nasional dengan membuat bahan ajar berupa modul.

\section{Mengembangkan instrumen penilaian}

Dalam kegiatan penelitian ini instrumen penilaian yang digunakan adalah pretest, angket pendahuluan, angket ketahanan budaya dan posttest.

\section{Mengembangkan strategi pembelajaran}

Pada tahap ini ada beberapa kegiatan yang dilakukan, yaitu kegiatan sebelum pembelajaran, kegiatan pada saat pembelajaran, keikutsertaan siswa, evaluasi dan kegiatan lanjutan setelah pembelajaran.

\section{Pembuatan draft modul}

Bahan ajar berbasis sejarah lokal Situs Astana Gede Kawali berupa modul pembelajaran mata pelajaran sejarah yang dikembangkan adalah berjudul Situs Astana Gede 
Kawali. Komponen yang terdapat dalam modul adalah Bahan ajar berbasis sejarah lokal Situs Astana Gede Kawali berupa modul pembelajaran mata pelajaran sejarah yang dikembangkan adalah berjudul Situs Astana Gede Kawali. Komponen yang terdapat dalam modul: Pendahuluan, Kegiatan belajar, berisi uraian materi, soal latihan, rangkuman, tes formatif dan kunci jawaban serta Daftar pustaka.

\section{Evaluasi formatif}

Evaluasi formatif dilakukan oleh ahli materi, ahli desain pembelajaran, ahli bahasa Indonesia, dan siswa. Untuk mengevaluasi bahan ajar yang telah dibuat, maka dilakukan validasi oleh ahli materi dan bahan ajar untuk pembelajaran. Dalam kegiatan penelitian ini, sebagai validatornya adalah Maman, S.Pd.,M.Pd sebagai ahli desain dan bahan ajar dan Heri Heryana, S.Pd guru sejarah di SMA Plus Informatika Ciamis sebagai ahli uji materi pembelajaran.

Tabel 1.Hasil Validasi Ahli Materi

\begin{tabular}{|c|c|c|c|c|c|c|}
\hline \multirow[t]{2}{*}{ No } & \multirow[t]{2}{*}{ Aspek Penilaian } & \multicolumn{5}{|c|}{ Skor } \\
\hline & & $\mathbf{1}$ & 2 & 3 & 4 & 5 \\
\hline & Kesesuain isi materi dengan tujuan pembelajaran & & & & $\mathrm{X}$ & \\
\hline 2 & Kesesuain materi dengan tingkat pendidikan & & & & $\mathrm{X}$ & \\
\hline & Kebenaran cerita dengan sejarah & & & & & $\mathrm{X}$ \\
\hline Jum & & & & & 2 & 1 \\
\hline Jum & ah X skor & & & & $2 \times 4$ & $5 \times 1$ \\
\hline Jum & ah total & & & 1 & & \\
\hline Rera & & & & 4 , & & \\
\hline Kete & rangan & & & $\mathrm{Ba}$ & & \\
\hline
\end{tabular}

(Hasil penilaian kuesioner Uji Coba dari validator Heri Heryana)

Berdasarkan tabel di atas hasil uji materi oleh guru sejarah mempunyai jumlah total nilai 13 dengan rerata 4,3. Secara keseluruhan dinyatakan baik dan layak digunakan berdasarkan aturan penilaian yang berlaku dalam proses pembelajaran.

Tabel 2. Hasil Validasi Ahli Bahan Ajar dan Desain Pembelajaran

\begin{tabular}{|c|c|c|c|c|c|c|c|}
\hline \multirow[t]{2}{*}{ No } & \multirow[t]{2}{*}{ Aspek Penilaian } & \multirow[t]{2}{*}{ Pernyataan } & \multicolumn{5}{|c|}{ Skor } \\
\hline & & & 1 & 2 & 3 & 4 & 5 \\
\hline \multirow[t]{4}{*}{1} & Komunikasi & $\begin{array}{l}\text { Kemudahan bahasa bahan ajar } \\
\text { untuk dipahami }\end{array}$ & & & & $\mathrm{X}$ & \\
\hline & & Logika berfikir & & & $\mathrm{X}$ & & \\
\hline & & Kejelasan gambar & & & $\mathrm{X}$ & & \\
\hline & & Penggunaan bahasa & & & & $\mathrm{X}$ & \\
\hline \multirow[t]{4}{*}{2} & Desain teknis & Kualitas gambar & & & & $\mathrm{X}$ & \\
\hline & & $\begin{array}{l}\text { Kesesuaian gambar dengan } \\
\text { penjelasan materi }\end{array}$ & & & & $\mathrm{X}$ & \\
\hline & & Urutan penyajian & & & & $\mathrm{X}$ & \\
\hline & & Tampilan gambar & & & $\mathrm{X}$ & & \\
\hline 3 & Format tampilan & $\begin{array}{l}\text { Penggunaan jenis ukuran huruf } \\
\text { Tampilan layout bahan ajar }\end{array}$ & & & $\mathrm{X}$ & $\mathrm{X}$ & \\
\hline
\end{tabular}


Kesesuaian antara materi dengan $\quad \mathrm{X}$

Jumlah silabus pembelajaran

Jumlah X skor

$\begin{array}{ll}4 & 7\end{array}$

Jumlah total

$4 \times 3 \quad 7 \times 4$

Rerata

40

Keterangan

3,63

Baik

(Hasil Penilaian Validator Maman)

Berdasarkan tabel di atas menunjukan hasil validasi ahli bahan ajar dan desain pembelajaran mempunyai jumlah total nilai 40 dengan rerata 3,63 dan hal ini dinyatakan baik dan layak diterapkan dalam proses pembelajaran. Selanjutnya, hasil penilaian ahli bahasa Indonesia terhadap draft modul mata pelajaran sejarah Situs Astana Gede Kawali adalah 30,55 \% sangat baik/sesuai/sistematis/konsisten/memadai/menarik, dan 69,45\% masuk dalam kategori baik/sesuai/sistematis/ajeg/memadai/menarik.

\section{Tabel 3.Hasil Uji Coba Lapangan}

\begin{tabular}{|c|c|c|c|c|c|c|}
\hline \multirow{2}{*}{ No } & \multirow{2}{*}{ Kriteria Penilaian } & \multicolumn{5}{|c|}{ Skala Penilaian } \\
\hline & & $\mathbf{1}$ & 2 & 3 & 4 & 5 \\
\hline 1 & Penjelasan materi yang jelas & 0 & 0 & 5 & 10 & 6 \\
\hline 2 & Penjelasan materi yang menarik & 0 & 0 & 3 & 8 & 10 \\
\hline 3 & Pembelajaran yang memberikan motivasi & 0 & 0 & 2 & 5 & 14 \\
\hline 4 & Materi yang menarik & 0 & 0 & 1 & 4 & 16 \\
\hline 5 & Kejelasan bahasa saat menyampaikan materi & 0 & 0 & 5 & 6 & 10 \\
\hline 6 & Materi mudah dipahami & 0 & 0 & 4 & 10 & 7 \\
\hline 7 & Materi dapat menambah pengetahuan & 0 & 0 & 2 & 4 & 15 \\
\hline 8 & Materi sesuai dengan silabus pembelajaran di sekolah & 1 & 1 & 2 & 6 & 11 \\
\hline 9 & Kesesuaian tulisan dengan gambar dalam bahan ajar & 0 & 0 & 2 & 10 & 9 \\
\hline 10 & Cerita bahan ajar sesuai dengan sejarah & 0 & 0 & 1 & 3 & 17 \\
\hline 11 & Tampilan gambar yang menarik & 0 & 0 & 5 & 6 & 10 \\
\hline 12 & Foto gambar sesuai dengan penjelasan materi & 0 & 0 & 2 & 5 & 14 \\
\hline 13 & Isi bahan ajar secara keseluruhan menarik & 0 & 2 & 4 & 4 & 14 \\
\hline \multicolumn{2}{|r|}{ Jumlah } & 1 & 3 & 38 & 81 & 150 \\
\hline \multicolumn{2}{|c|}{ Jumlah X skala penilaian } & 1 & 6 & 114 & 324 & 750 \\
\hline \multicolumn{2}{|c|}{ Jumlah total } & \multicolumn{5}{|c|}{1195} \\
\hline \multicolumn{2}{|c|}{ Rerata } & \multicolumn{5}{|c|}{4,37} \\
\hline \multicolumn{2}{|c|}{ Keterangan } & & & Baik & & \\
\hline
\end{tabular}

Keterangan:

Indikator 1-3 aspek pembelajaran

Indikator 4-8 aspek materi

Indikator 9-13 aspek bahan ajar

Dari tabel tersebut menunjukkan bilamana secara keseluruhan bahan ajar Situs

Astana Gede Kawali yang dikembangkan peneliti adalah baik dan layak digunakan berdasarkan hasil penilaian siswa. Hal ini berdasarkan nilai yang diperoleh secara keseluruhan yaitu, 4,37. Angka ini termasuk kriteria baik berdasarkan rentang nilai yang diterapkan. Selanjutnya, revisi produk pengembangan yang disampaikan oleh ahli materi, 
ahli bahan ajar dan desain pembelajaran, ahli bahasa Indonesia serta siswa merupakan salah satu cara supaya produk bahan ajar yang diperoleh sesuai dengan standar kebutuhan belajar siswa. Saran ahli materi terhadap draft bahan ajar berupa modul sejarah lokal Situs Astana Gede Kawali adalah materi sejarah Situs Astana Gede Kawali sebaiknya mencantumkan sumber yang data dan faktanya bisa dipertanggungjawabkan, serta materi yang sesuai dengan kebenaran sejarah. Kemudian saran ahli bahan ajar dan desain pembelajaran terhadap draft bahan ajar modul sejarah lokal adalah bahwa bahan ajar harus disesuaikan dengan materi yang sudah ada di sekolah serta mengikuti sistematika yang sudah baku, sebaiknya dilengkapi dengan latihan-latihan soal yang mampu meningkatkan pemahaman siswa terhadap sejarah lokal. Sedangkan saran ahli bahasa Indonesia adalah bahwa penulisan bahan ajar harus menggunakan bahasa yang baku dan mudah dipahami oleh siswa. Saran siswa tatkala pelaksanaan uji lapangan supaya modul sejarah lokal Situs Astana Gede Kawali diperbanyak dan keberlanjutannya bisa dibuatkan bahan ajar situs-situs sejarah lokal yang lainnya yang ada di kabupaten Ciamis.

\section{Kesimpulan}

Berdasarkan hasil penelitian yang diperoleh, maka dapat disimpulkan sesuai dengan fokus penelitian bahwa Pembelajaran sejarah di SMA Informatika Ciamis selama ini masih menggunakan metode, model yang masih bersifat konvensional; Penggunaan situs sejarah lokal sebagai bahan ajar dalam proses pembelajaran belum dilakukan secara optimal; Pengembangan bahan ajar berbasis sejarah lokal Situs Astana Gede Kawali dilakukan dengan mengembangkan bahan ajar yang sudah ada dan dilakukan pembaharuan serta disesuaikan dengan Standar Kompetensi, Kompetensi Dasar dan Materi Pokok pembelajaran. Penerapan bahan ajar berbasis sejarah lokal Situs Astana Gede Kawali efektif meningkatkan ketahanan budaya dan hasil belajar siswa. Hal ini ditunjukkan dari hasil evaluasi belajar dan aktifitas pembelajaran yang sangat baik.

\section{Daftar Pustaka}

Anggoro, Dimas; Wasino, S. (2020). Pengembangan Modul Bahan Ajar Sejarah Berbasis Perjuangan Masyarakat Tengaran Selama Revolusi Fisik Untuk Meningkatkan Nasionalisme. Swadesi: Jurnal Pendidikan Dan Ilmu Sejarah, I, 47-59. https://doi.org/http://dx.doi.org/10.26418/jurnal\%20swadesi.v1i1.35944

Anik, G. (2011). Pendekatan Penelitian dan Pengembangan Dibidang Pendidikan dan Pembelajaran. http://staff.uny.ac.id/sites/default/files/HAND OUT MODEL R \& D.pdf

Darmawan, W. (n.d.). Sejarah Lokal: ( Pengertian, Konten, dan (pp. 1-11). http://file.upi.edu/Direktori/FPIPS/JUR._PEND._SEJARAH/197101011999031WAWAN_DARMAWAN/Peng_sej_Lokal.pdf

Hardiana, Y. (2017). Pembelajaran Sejarah Indonesia Berbasis Peristiwa-Peristiwa Lokal di 
Tasikmalaya untuk Meningkatkan Kemampuan Berpikir Kritis Siswa. Historia: Jurnal Pendidik Dan Peneliti Sejarah, I(1), 41-46. https://doi.org/https://doi.org/10.17509/historia.v1i1.7008

Haryati, S. (2012). Research And Development (R\&D) Sebagai Salah Satu Model Penelitian Dalam Bidang Pendidikan. Majalah Ilmiah Dinamika, 37, No. 1, 11-26.

Kusnoto, Y., \& Minandar, F. (2017). Pembelajaran Sejarah Lokal : Sosial Horizon: Jurnal Pendidikan Sosial, $4(1)$, 125-137. https://doi.org/http://dx.doi.org/10.31571/sosial.v4i1.428

Novianti, Sudjarwo, \& Pargito. (2015). pengembangan bahan ajar sejarah berupa cerita rakyat sebagai wujud kearifan-lokal [Universitas Lampung]. https://docplayer.info/46564769-Pengembangan-bahan-ajar-sejarah-berupacerita-rakyat-sebagai-wujud-kearifan-lokal-1-oleh-novianti-2-sudjarwo-3-pargito4.html

Romadi dan Kurniawan, Ganda Febri. (2017). Pembelajaran Sejarah Lokal Berbasis Folklore Untuk Menanamkan Nilai Kearifan Lokal Kepada Siswa. Sejarah Dan Budaya, XI, No 1(2), 79-94. https://doi.org/http://dx.doi.org/10.17977/sb.v11i1.9123

Wijayanti, Yeni, dkk. (2016). Media Pembelajaran Berbasis Audio Visual Situs Kerajaan Galuh di Ciamis Untuk Meningkatkan Kesadaran Sejarah Siswa di SMA N 1 Ciamis. Penelitian Hibah Kemenristekdikti.

Wiyanarti, E. (2017). Model Pembelajaran Kontekstual Dalam Pengembangan Pembelajaran Sejarah. Departemen Pendidikan Sejarah UPI. http://sejarah.upi.edu/artikel/dosen/model-pembelajaran-kontekstual-dalampengembangan-pembelajaran-sejarah/. 